Article

\title{
Interaction and Assembly of Bacterial Communities in High-Latitude Coral Habitat Associated Seawater
}

\author{
Yu Chen ${ }^{1,2}$, Jie Li ${ }^{1, *}$, Yuanjiao Lyu ${ }^{1}$, Yiyang Zou ${ }^{1}$, Qiqi Li ${ }^{1}$, Qingsong Yang ${ }^{1}$, Xiaoyu Tang ${ }^{1}$, \\ Xiangcheng Yuan ${ }^{1,3,4}$, Zhijian Jiang ${ }^{1}$ and Si Zhang ${ }^{1,2}$
}

Citation: Chen, Y.; Li, J.; Lyu, Y.; Zou, Y.; Li, Q.; Yang, Q.; Tang, X.; Yuan, X.; Jiang, Z.; Zhang, S. Interaction and Assembly of Bacterial Communities in High-Latitude Coral Habitat Associated Seawater. Microorganisms 2022, 10, 558. https://doi.org/ $10.3390 /$ microorganisms 10030558

Academic Editor: Nico Jehmlich

Received: 27 January 2022

Accepted: 1 March 2022

Published: 3 March 2022

Publisher's Note: MDPI stays neutral with regard to jurisdictional claims in published maps and institutional affiliations.

Copyright: (C) 2022 by the authors. Licensee MDPI, Basel, Switzerland. This article is an open access article distributed under the terms and conditions of the Creative Commons Attribution (CC BY) license (https:// creativecommons.org/licenses/by/ $4.0 /)$.
1 CAS Key Laboratory of Tropical Marine Bio-Resources and Ecology, South China Sea Institute of Oceanology, Chinese Academy of Sciences, Guangzhou 510301, China; chenyu@gmlab.ac.cn (Y.C.);

yjlv_dr_em@outlook.com (Y.L.); zouyiyang18@mails.ucas.ac.cn (Y.Z.); liqiqi19@mails.ucas.ac.cn (Q.L.); qsyang@scsio.ac.cn (Q.Y.); txy506@126.com (X.T.); xcyuan@scsio.ac.cn (X.Y.); jiangzj1982@scsio.ac.cn (Z.J.); zhsimd@scsio.ac.cn (S.Z.)

2 Southern Marine Science and Engineering Guangdong Laboratory, Guangzhou 511458, China

3 Key Laboratory of Tropical Marine Biotechnology of Hainan Province, South China Sea Institute of Oceanology, Chinese Academy of Sciences, Guangzhou 510301, China

4 Sanya National Marine Ecosystem Research Station, South China Sea Institute of Oceanology, Chinese Academy of Sciences, Sanya 572024, China

* Correspondence: lijietaren@scsio.ac.cn

\begin{abstract}
Threatened by climate change and ocean warming, coral reef ecosystems have been shifting in geographic ranges toward a higher latitude area. The water-associated microbial communities and their potential role in primary production contribution are well studied in tropical coral reefs, but poorly defined in high-latitude coral habitats to date. In this study, amplicon sequencing of 16S rRNA and $c b b L$ gene, co-occurrence network, and $\beta$ NTI were used. The community structure of bacterial and carbon-fixation bacterial communities showed a significant difference between the center of coral, transitional, and non-coral area. Nitrite, DOC, $\mathrm{pH}$, and coral coverage ratio significantly impacted the $\beta$-diversity of bacterial and carbon-fixation communities. The interaction of heterotrophs and autotrophic carbon-fixers was more complex in the bottom than in surface water. Carbon-fixers correlated with diverse heterotrophs in surface water but fewer lineages of heterotrophic taxa in the bottom. Bacterial community assembly showed an increase by deterministic process with decrease of coral coverage in bottom water, which may correlate with the gradient of nitrite and $\mathrm{pH}$ in the habitat. A deterministic process dominated the assembly of carbon-fixation bacterial community in surface water, while stochastic process dominated $t$ the bottom. In conclusion, the structure and assembly of bacterial and carbon-fixer community were affected by multi-environmental variables in high-latitude coral habitat-associated seawater.
\end{abstract}

Keywords: high-latitude scleractinian coral habitat; water-associated bacteria; carbon-fixation bacteria; interaction; community assembly

\section{Introduction}

Coral reefs are highly diverse and productive ecosystems [1,2]. The gross primary production rates of coral reefs range from 256 to $1696 \mathrm{mmol} \mathrm{C} \mathrm{m}^{-2} \mathrm{~d}^{-1}$ [3,4]. Benthos including coral symbiotic zooxanthellae, macroalgae, algal, turfs, and endolithic algae contribute a major fraction of the primary production in the ecosystem [5,6], while planktonic creatures contribute up to $13 \%$ of the primary production [4,5]. Moreover, environmental microbes may play a key role against reef degradation by altering its productivity and trophic dynamics [7]. Thus, environmental microbes are crucial for productivity and maintenance of coral reefs.

Benthos influences the reef water column environment at different scales [8], and bacterial communities have been found that are highly diverse and vary among reef water 
habitats on large scale [9]. Alphaproteobacteria, Betaproteobacteria, Gammaproteobacteria, and Cyanobacteria were high in abundance in coral reef water column $[7,10]$. The abundance of Gammaproteobacteria increased with distance away from reef, while Alphaproteobacteria decreased [9]. Betaproteobacteria was ubiquitous and did not show obvious variation in abundance across the gradient [9]. Synechococcus, one of the predominant carbon fixers, was found in greater abundances in the south reefs in Red Sea, where water temperature is $4{ }^{\circ} \mathrm{C}$ higher on average $[11,12]$. Prochlorococcus was more abundant in the relative oligotrophic north part of Red Sea $[10,11]$, suggesting that different Cyanobacteria taxa showed diverse preference in response to temperature and nutrient supplement. Interestingly, the autotrophic carbon-fixers usually interact with heterotrophic bacteria. Such interaction had a pivotal effect on the efficiency of carbon-fixation [13], which directly influenced the primary production rate in coral reefs.

Bacterial community structure is mainly governed by deterministic processes in the ocean [14]. Many researches have focused on the coral-associated bacterial community assembly, but few on water-associated bacterial community assembly in reefs were found. In the Great Barrier Reef, seawater microbiomes were characterized by uniform community assembly patterns [15]. Similar assembly patterns were also found in cold-water coral reef ecosystems. The bacterial community was dominantly structured by the deterministic effect of microbial habitat type and the strong effect of reef location [16]. Taken together, the assembly of bacterial community in reef water was dominantly driven by deterministic effects.

Corals secrete organic-rich mucus into seawater, affecting the environmental microbial community in a continuous profile but on a small-scale [7]. Large scale surveys may ignore the effect of reef benthos, especially corals, to the seawater microbial community. Coral reefs are proposed to fix about 900 million tons of carbon per year on a global scale [17-19], indicating them to be potential blue carbon sinks. Therefore, it is of great importance to evaluate the effect of corals on seawater microbial community, especially the carbon-fixation community, more precisely. Over the past century, poleward migration of scleractinian corals was frequently reported due to the rising ocean surface temperature [20-22]. The high-latitude environments were considered to serve as climate change "refugia" for tropical coral reef species [22,23]. However, the dynamics and assembly of environmental microbiome in high-latitude scleractinian coral habitats were also unclarified, which is an obstacle to understanding the development and adaptability of high-latitude coral communities and their ecological effects. How do the water-associated bacterial and carbon-fixation bacterial community distribute in high-latitude scleractinian coral habitats? And how do they interact and assemble? To address these questions, we (1) identified the bacterial and carbon-fixation bacterial community structures in a scleractinian coral habitat in Miaowan Island, South China Sea (SCS); (2) examined the correlation of heterotrophic bacteria and autotrophic carbon-fixation bacteria; and (3) determined the assembly patterns of bacterial and carbon-fixation bacterial communities.

\section{Materials and Methods}

\subsection{Sample Collection}

Miaowan Island $\left(21^{\circ} 52^{\prime} \mathrm{N}, 114^{\circ} 01^{\prime} \mathrm{E}\right)$ was in the northern SCS (Figure 1A). Sampling was carried out in a small coral community at a bay of Miaowan Island. According to previous investigations, including our own, the coverage ratio of coral is $20 \%$ at the center of coral habitat (Station WA) and 5\% at the marginal area (Station WB, approximately $15 \mathrm{~m}$ from WA). A non-coral area was selected as control (Station WC, approximately $40 \mathrm{~m}$ from WA). Seawater temperature was $28.1 \pm 0.2{ }^{\circ} \mathrm{C}$. Seawater samples were collected at the surface layer ( $0.5 \mathrm{~m}$ depth) and the bottom layer $(n=6$, Figure $1 \mathrm{~B})$ with the assistance of a diver. Two liters of seawater was filtered onto $0.22 \mu \mathrm{m}$ membrane filter (Millipore, Billerica, MA, USA) for DNA extraction and stored in liquid nitrogen. The map was drawn with Ocean Data View 5.4.0. The diagram of sampling sites was created with BioRender (https:/ / biorender.com/ (accessed on 4 April 2021)). 
(A)

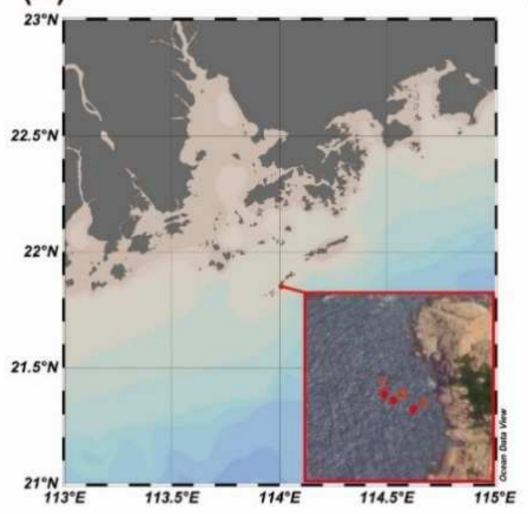

(B)

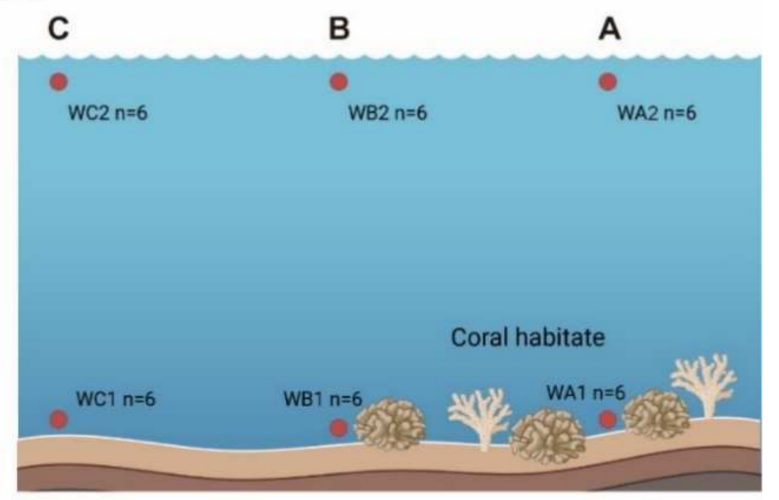

Figure 1. Map of the sampling stations. (A) Location of Miaowan Island in South China Sea and location of sampling stations. (B) Sampling sites of each station are in the surface and bottom of the water column. Station A is in the center of coral habitat. Station B is the marginal area of coral habitat. Station $\mathrm{C}$ is the non-coral area.

Environmental metadata, including salinity, dissolved oxygen (DO), and $\mathrm{pH}$, was recorded on board with YSI probe (YSI Pro Plus, Yellow Springs, Ohio, USA). The bottom depth of each sample site was measured using a depth sounder. The concentrations of nitrate, nitrite, ammonium, phosphate, and silicate were measured following the Chinese national standard methods GB 17378.4-2007. The DOC and DIC concentrations were analyzed using a Shimadzu TOC-L carbon analyzer. Chla was measured by acetone method after extraction with acetone for $24 \mathrm{~h}$ in the dark.

\subsection{DNA Extraction, Amplification, and Sequence Analysis}

Filters were cut into small pieces, and DNA was extracted using MO BIO Power Soil DNA Kit (Mo Bio, Carlsbad, CA, USA) according to the manufacturer's instruction. Fifty nanograms of DNA was used as a template for PCR amplification. The V3V4 region of $16 \mathrm{~S}$ rRNA genes were amplified with primers $338 \mathrm{~F}$ and $806 \mathrm{R}$ [24]. PCR progress was shown as follows: $94{ }^{\circ} \mathrm{C}$ for $5 \mathrm{~min}$; followed by 30 cycles of $94{ }^{\circ} \mathrm{C}$ for $30 \mathrm{~s}, 52{ }^{\circ} \mathrm{C}$ for $30 \mathrm{~s}, 72{ }^{\circ} \mathrm{C}$ for $30 \mathrm{~s}$; and finished with $72{ }^{\circ} \mathrm{C}$ for $10 \mathrm{~min}$. The $c b b L$ gene encodes the large subunit of RubisCO type I, a key gene involved in the most distributed $\mathrm{CO}_{2}$-fixing pathway [25]. They were amplified with primers $c b b L_{-} \mathrm{K} 2 \mathrm{f}$ and $c b b L_{-} \mathrm{V} 2 \mathrm{r}$ [25] following the PCR progress: $94{ }^{\circ} \mathrm{C}$ for $3 \mathrm{~min}$; followed by 5 cycles of $94{ }^{\circ} \mathrm{C}$ for $30 \mathrm{~s}, 45^{\circ} \mathrm{C}$ for $20 \mathrm{~s}, 65^{\circ} \mathrm{C}$ for $30 \mathrm{~s}$; then, 20 cycles of $94{ }^{\circ} \mathrm{C}$ for $20 \mathrm{~s}, 55{ }^{\circ} \mathrm{C}$ for $20 \mathrm{~s}, 72{ }^{\circ} \mathrm{C}$ for $30 \mathrm{~s}$; and finished with $72{ }^{\circ} \mathrm{C}$ for $5 \mathrm{~min}$. Three replicates were pooled and purified using the QIAquick Gel Extraction Kits (QIAGEN GmbH). Product quality was assessed using a NanoDrop spectrophotometer (Thermo Scientific, Vantaa, Finland) and sequenced using an Illumina HiSeq platform with $2 \times 250$ bp paired-end reads for $16 \mathrm{~S}$ rRNA gene amplicons, and Illumina MiSeq platform with $2 \times 300$ bp paired-end reads for $c b b L$ gene amplicons.

Raw reads were quality-filtered using Fastp v0.14.1 [26] and merged using Usearch v10.0.240 [27] with a minimum overlap of five nucleotides. Maximum allowed error rate in the overlap region was 0.2 . The resulting sequences were grouped by barcode using QIIME v1.9.1 [28] and were clustered as operational taxonomic units (OTUs) at 97\% sequence identity using UPARSE [29]. Singleton OTUs and chimeras were removed using Usearch v10.0.240 [27] and UCHIME v4.2.40 de novo algorithm [30], respectively. OTUs were taxonomically identified using the SILVA v132 database and VSEARCH global alignments for $16 \mathrm{~S}$ rRNA gene [31], and NCBI-NR database for $c b b L$ gene. Mitochondria, chloroplasts, archaea, eukaryotes, unidentified sequences, and OTUs with abundances below $0.005 \%$ (minimum number of representative sequences) were removed [32]. The nucleotide sequences were deposited at the NCBI Sequence Read Archive under the BioProject number PRJNA762627. 


\subsection{Statistical Analysis}

Alpha diversity indices including Richness, Chao1, Shannon, and Simpson index were calculated with Picante [33] package in R. Non-metric multidimensional scaling (NMDS) analysis by Bray-Curtis distance was applied for illustrating the compositions of total 16S rRNA and $c b b L$ OTUs in all groups. The analysis of similarities (ANOSIM), redundancy analysis (RDA), and Mantel test were calculated with Vegan [34] package in R. Construction of Neighbor-joining phylogenetic trees (bootstraps $=1000$ ) for top $70 c b b L$ OTU sequences was performed with megaX [35]. Key OTUs for bacterial communities were selected by Random Forest machine learning with the randomForest [36] package in R. Cooccurrence network of carbon fixers and heterotrophs in surface or bottom water $(n=18)$ were computed using the CoNet (v1.1.1.beta) plugin within Cytoscape (v3.7.2). $\beta$-meannearest taxa distance ( $\beta M N T D$ ) was calculated with Picante [33] package in R. To generate the null distribution, random shuffling of OTU labels across the tips of the phylogeny was calculated 999 times. $\beta$ NTI was calculated to represent the difference between observed $\beta$ MNTD and the mean of the null distribution $(|\beta N T I|>2$ : deterministic; $|\beta N T I|<2$ : stochastic) [37].

\section{Results}

\subsection{Alpha Diversity of Bacteria and Carbon-Fixation Bacteria}

For 16S rRNA gene sequencing, a total of 3,162,205 reads were recovered from sequencing of the mixture of PCR amplicons of the pooled DNA. OTUs were defined at a sequence similarity cut-off of $97 \%$ using average linkage hierarchical clustering. In surface seawater, the Richness and Chao1 indices of 16S rRNA genes were significantly higher in non-coral station (WC2) than in coral-associated areas (WA2 and WB2). The Shannon and Simpson indices were similar. In bottom seawater, the Richness, Chao1, and Shannon indices of 16S rRNA genes were significantly higher in non-coral station (WC1), while the Simpson index was similar (Figure S1).

For $c b b L$ gene sequencing, 6,442,176 reads were obtained. OTUs were also defined at $97 \%$ of sequence similarity. Alpha diversity of $c b b L$ genes was similar to the $16 \mathrm{~S}$ rRNA genes in all stations. In surface seawater, the Richness and Chao1 indices of $c b b L$ genes were significantly higher in non-coral station (WC2). In bottom seawater, the Richness, Chao1, and Shannon indices of $c b b L$ genes were also significantly higher in non-coral station (WC1, Figure S2). Simpson index did not show a significant difference in surface or bottom water.

\subsection{Composition of Bacterial and Carbon-Fixation Bacterial Community}

In total bacterial community, Proteobacteria (37.8-43.7\%), Actinobacteria (23.2-26.6\%), Cyanobacteria (17.7-27.8\%), and Bacteroidetes (4.6-9.0\%) were the dominant groups (Figure S3). In surface water, the relative abundance of Cyanobacteria was significantly higher, while Bacteroidetes was significantly lower in the non-coral station (WC2) than coral-associated stations (WA2 and WB2, One-way ANOVA $p<0.05$ ). The relative abundance of Proteobacteria and Actinobacteria did not show significant difference in all sites. In bottom water, only the relative abundance of Bacteroidetes was found significantly lower in non-coral station (WC1) than coral-associated stations (WA1 and WB1, One-way ANOVA $p<0.05$ ), while the abundance of Proteobacteria, Actinobacteria, and Cyanobacteria was unchanged among all sites (Figure 2A).

In carbon-fixation communities, Synechococcus was the predominant genus, with relative abundance that ranged from $76.1 \%$ to $97.5 \%$ (Figure S3). Its relative abundance was significantly higher in coral-associated stations (WA1/WA2/WB1/WB2) than in noncoral stations (WC1/WC2, One-way ANOVA $p<0.05$ ) in both surface and bottom water. Thioalkalivibrio was the second most abundant genus, whose relative abundance ranged from 1.2 to $5.8 \%$. It was significantly more abundant in non-coral stations (WC1/WC2, Figure 2B).

Distribution specificity of bacteria was assessed by comparing the similarities of communities. NMDS based on Bray-Curtis dissimilarities revealed a clear separation 
of the bacterial communities from different stations (Figure 2C). Such specificity was further confirmed by ANOSIM analysis. In surface water, the bacterial communities of WA2 and WB2 did not show significant difference $(R=0.1287, p=0.108)$. However, bacterial community of WC2 significantly varied from WA2 $(\mathrm{R}=0.8611, p=0.003)$ and WB2 $(\mathrm{R}=0.4667, p=0.005)$. In bottom water, communities of three stations varied significantly (WA1/WB1, $\mathrm{R}=0.3315, p=0.006$; WA1 $/ \mathrm{WC1}, \mathrm{R}=0.7046, p=0.003$; WB1 $/ \mathrm{WC1} 1 \mathrm{R}=0.8148$, $p=0.001)$.
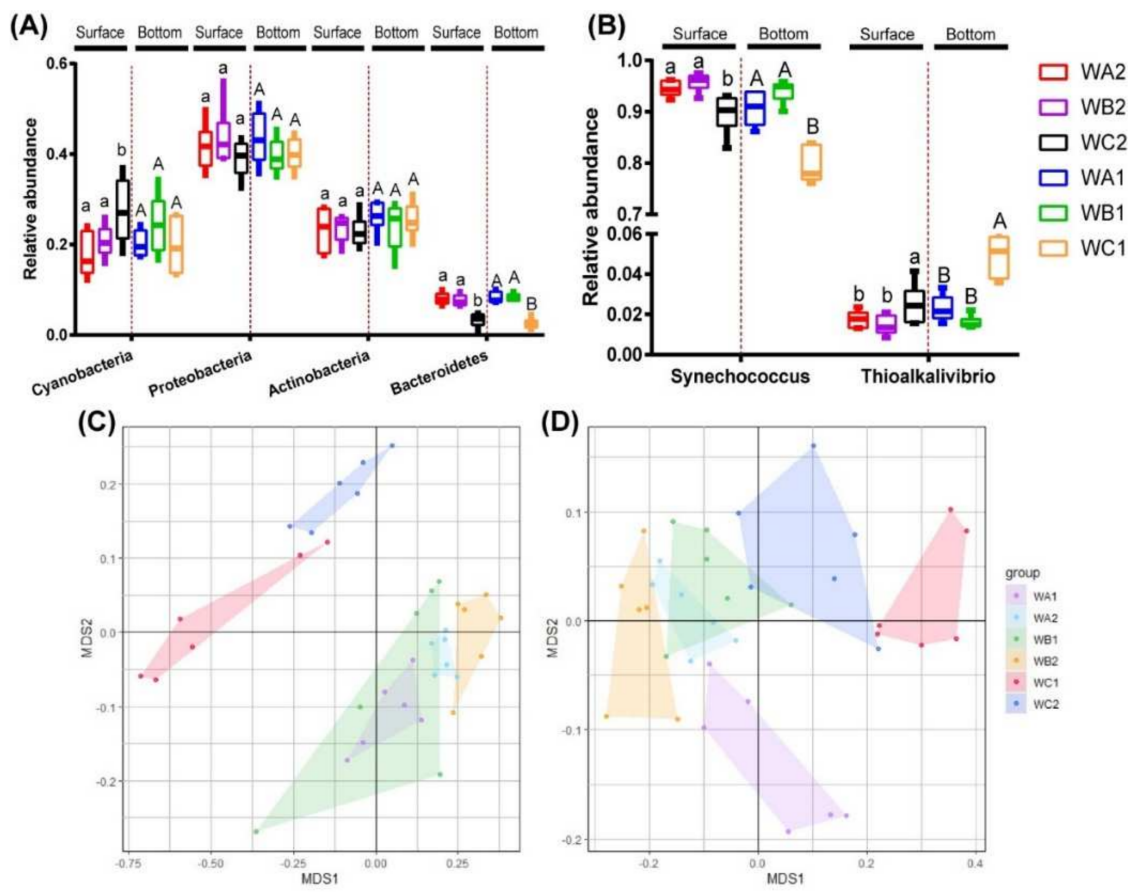

Figure 2. Relative abundance of key taxa and beta diversity of bacterial and carbon-fixation bacterial community. (A) Variation in relative abundance of bacterial phylum ( $>5 \%)$ between areas. (B) Variation in relative abundance of carbon-fixation bacterial genus $(>1 \%)$ between areas. NMDS ordinations based on Bray-Curtis dissimilarity shows the compositions of total 16S rRNA (C) and $c b b L$ (D) gene OTUs.

Carbon-fixation communities were also separately revealed by Bray-Curtis dissimilaritybased NMDS analysis (Figure 2D). Similar to the bacterial communities, carbon-fixation communities of WA2 and WB2 did not vary significantly $(R=0.1333, p=0.096)$, while WC2 showed significant difference in surface water (WA2/WC2, $\mathrm{R}=0.8741, p=0.003$; WB2 $/ \mathrm{WC} 2, \mathrm{R}=0.4833, p=0.004)$. In bottom water, communities of three stations varied significantly (WA1/WB1, $\mathrm{R}=0.3574, p=0.008 ; \mathrm{WA1} / \mathrm{WC1}, \mathrm{R}=0.7167, p=0.003 ; \mathrm{WB1} / \mathrm{WC1}$, $\mathrm{R}=0.8481, p=0.003)$.

\subsection{Relationship between Microbial Communities and Environment}

The relationship of microbial communities and environmental metadata was analyzed via transformation-based redundancy analysis (tb-RDA) and partial Mantel tests, respectively. Environmental metadata including water depth (Depth); concentration of nitrite, ammonium, nitrate, phosphate, silicate, and chlorophyll a (Chla); DOC; DIC; salinity (Sal); $\mathrm{pH}$; and coral coverage ratio (Coverage) were analyzed. For bacterial community, stepwise forward selection indicated that nitrite concentration and coral coverage ratio were the best predicators, explaining $18 \%$ (axis 1: $66.7 \%$, axis $2: 20.0 \%$ after stepwise forward selection) of the total variables. Coral coverage ratio was positively correlated with $\beta$-diversity of bacterial community at coral-associated stations (WA and WB), while concentration of nitrite was positively correlated with that at non-coral station (WC, Figure 3A). Partial Mantel tests indicated that coral coverage ratio was significantly correlated with changes 
in bacterial communities in both surface and bottom water, while concentrations of DOC and $\mathrm{pH}$ were significantly correlated with bacterial community changing in surface water (Table S1).

(A)

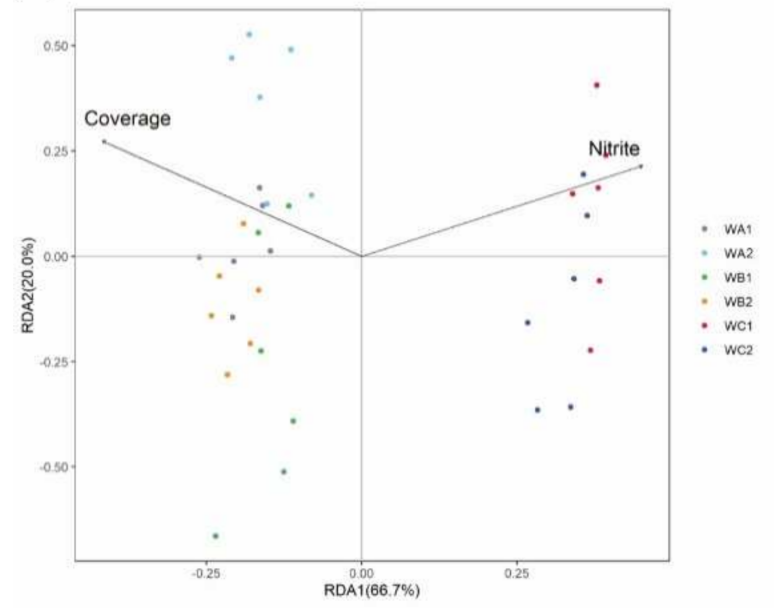

(B)

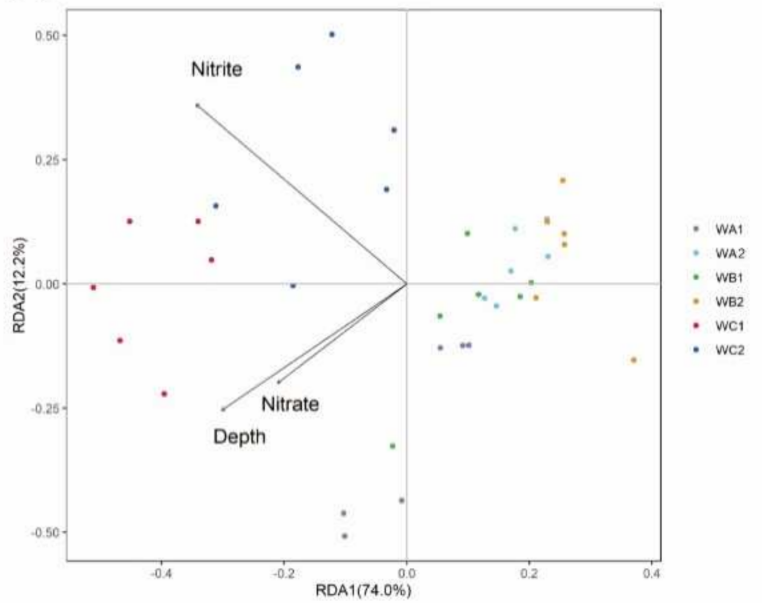

Figure 3. Ordination diagrams from redundancy analysis (RDA) of $16 \mathrm{~S}$ rRNA (A) and $c b b L$ (B) communities and environmental parameters $(n=6)$. Arrows indicate the direction and magnitude of environmental variables associated with $16 \mathrm{~S}$ rRNA and $c b b L$ community structures. Each sample is represented by a colored circle.

For carbon-fixation communities, tb-RDA with stepwise forward selection indicated water depth and concentration of nitrate, and nitrite explained 23\% (axis 1: $74.0 \%$, axis 2: 12.2\% after stepwise forward selection) of the total variables. These parameters were negatively correlated with $\beta$-diversity of the community at coral-associated stations (WA and WB), but positively correlated with non-coral station (WC, Figure 3B). Partial Mantel tests show that coral coverage ratio was significantly correlated with changing of carbon-fixation communities in both surface and bottom water, while concentration of nitrite and $\mathrm{pH}$ were significantly correlated in surface water (Table S2).

\subsection{Phylogenetic Diversity of Carbon-Fixation Bacteria}

Phylogenetic analysis was conducted with cbbL gene OTUs with relative abundance $>0.1 \%$. Seventy representative OTUs were retrieved and their deduced amino acid sequences were used for Neighbor-joining tree construction (Figure 4). Accordingly, these OTUs were manually divided into seven clusters based on bootstrap values (bootstrap > 0.6). Cluster 1 was the most abundant group (82.1\%), with OTUs affiliating to Synechoccocus. They clustered with two known Synechoccocus species and five uncultured microorganisms. Clusters two to seven all grouped with uncultured microorganisms (Figure 4). Cluster two contained OTUs affiliating to Thioalkalivibrio, with relative abundance of $0.4 \%$. Cluster three contained one OUT affiliating to Chromatiales, with relative abundance of $0.1 \%$. OTUs from Cluster four affiliated to Gammaproteobacteria, with relative abundance of $1.0 \%$ in total. Cluster five and six contained OTUs affiliating to Chromatiaceae, with relative abundance of $0.3 \%$ and $0.6 \%$, respectively. Cluster seven contained OTUs affiliating to Chromatiales, with relative abundance of $0.9 \%$.

\subsection{Interaction of Key Bacteria and Carbon-Fixers}

A total of 30 key 16S rRNA gene OTUs were selected via Random Forest analysis for surface (Figure 5A) and bottom (Figure 5B) water, respectively. The key OTUs largely belonged to heterotrophic bacteria. Co-occurrence network of key $16 \mathrm{~S}$ rRNA gene OTUs and the $c b b L$ gene clusters was more complex in bottom water than in the surface (Figure 5C,D). A total of 369 edges were present in the network for bottom water, while 186 edges in 
surface water. In surface water, five clusters were correlated with the key OTUs. Cluster 2 positively correlated with two OTUs from Actinobacteria, two from Chloroflexi and four from Proteobacteria, while it negatively correlated with one OTU from Bacteroidetes and three from Proteobacteria. Cluster four positively correlated with one OTU from Actinobacteria, two from Chloroflexi, and three from Proteobacteria, while it negatively correlated with two from Proteobacteria. Cluster five positively correlated with two OTUs from Actinobacteria, two from Chloroflexi, and four from Proteobacteria, but negatively correlated with one from Bacteroidetes and Proteobacteria, respectively. Cluster six positively correlated with two OTUs from Actinobacteria, Chloroflexi, and Proteobacteria respectively, while it negatively correlated with one OTU from Bacteroidetes and three from Proteobacteria. Cluster seven positively correlated with two OTUs from Bacteroidetes, two from Verrucomicrobia, and one from Proteobacteria, while it negatively correlated with one OTU from Planctomycetes (Figure 5C, Table S3).

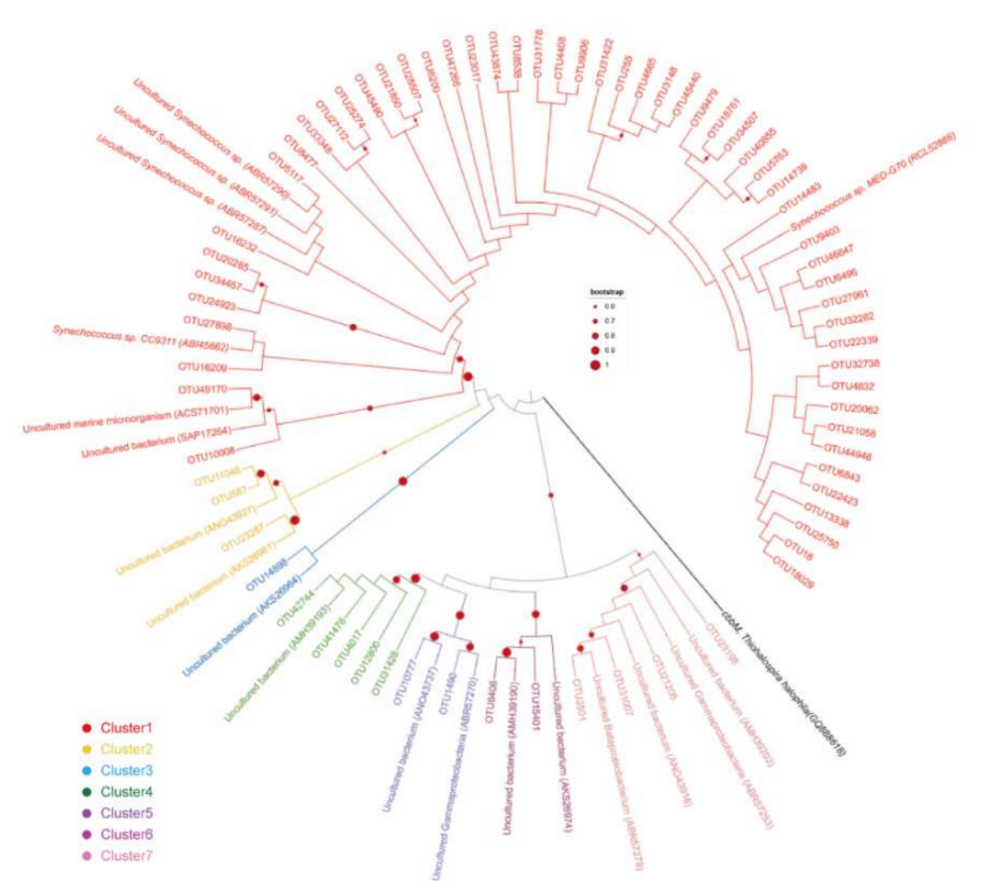

Figure 4. Neighbor-joining tree obtained from deduced amino acid sequences of representative $c b b L$ OTUs, together with reference sequences retrieved from the NCBI database. The OTUs with relative abundance over 0.001 were selected for phylogenetic analysis and these OTUs were manually divided into seven clusters based on sequence similarity. The $c b b M$ gene from Thiohalospira halophila is used as out group. One thousand bootstrap replicates were performed. Nodes with bootstrap value over 0.6 were marked.

In bottom water, five of the $c b b L$ gene clusters co-occurred with key OTUs, but the clusters were different from those in surface water. Cluster one positively correlated with three OTUs from Bacteroidetes, two from Proteobacteria, and three from Verrucomicrobia, while it negatively correlated with one OTU from Actinobacteria, two from Chloroflexi, and five from Proteobacteria. Cluster two, four, five, and six showed similar profiles in correlation with key OTUs. They all positively correlated with one OTU from Actinobacteria, three from Chloroflexi, eight from Proteobacteria, one from Verrucomicrobia, and one from Gemmatimonadetes, while it negatively correlated with Bacteroidetes, Proteobacteria, and Verrucomicrobia taxa (Figure 5D, Table S4).

\subsection{Assembly of Bacterial and Carbon-Fixation Bacterial Communities}

The $\beta$ NTI for each station were calculated. For bacterial community, $26.7 \%$ and $13.3 \%$ of the absolute $\beta$ NTI values were $>2$ in WA2 and WC2 station in the surface, and none 
of the $\beta$ NTI values fell in this area at WB2. While in bottom water, $13.3 \%, 20 \%$, and $40 \%$ of the absolute $\beta$ NTI values were $>2$ in WA1, WB1, and WC1, respectively. In addition, the proportion showed an increase along with distance to coral community (Figure 6A), suggesting that bacterial community was dominantly assembled with stochastic pattern in surface water, while the environmental impacts increased on community assembly with distance to center of coral habitat in the bottom. For carbon-fixation community, the proportions of absolute $\beta$ NTI values $>2$ were $40 \%, 66.7 \%$, and $20.0 \%$ in WA2, WB2, and WC2 in the surface, respectively. In the bottom, $33.3 \%, 26.7 \%$, and $26.7 \%$ of absolute $\beta$ NTI values were $>2$ in WA1, WB1, and WC1, respectively (Figure 6B), indicating that assembly of the carbon-fixation bacterial community was dominated by a deterministic process in surface water, but dominated by a stochastic process at the bottom.

(A)

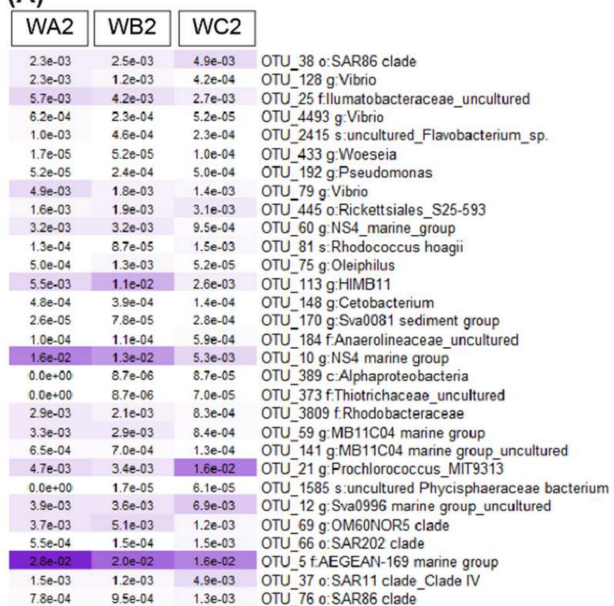

(B)

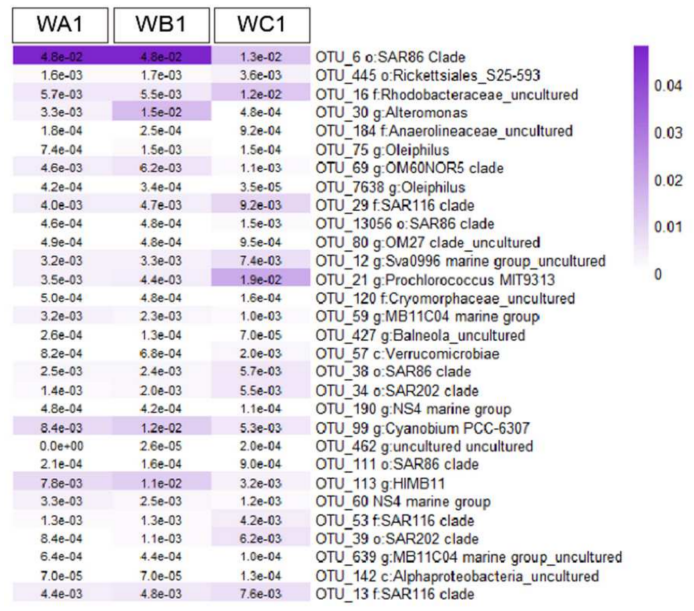

(C)

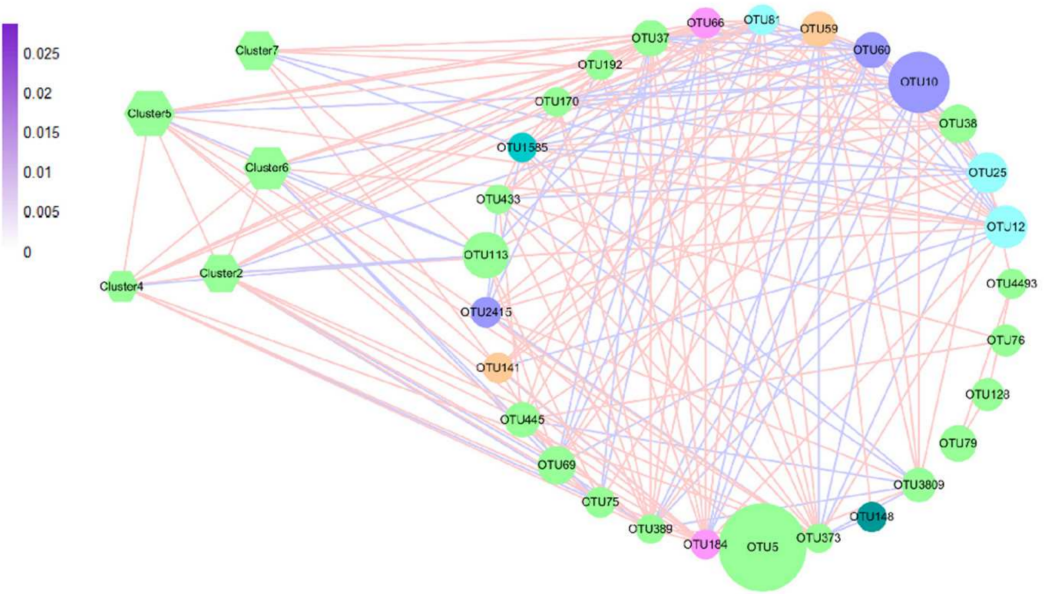

(D)

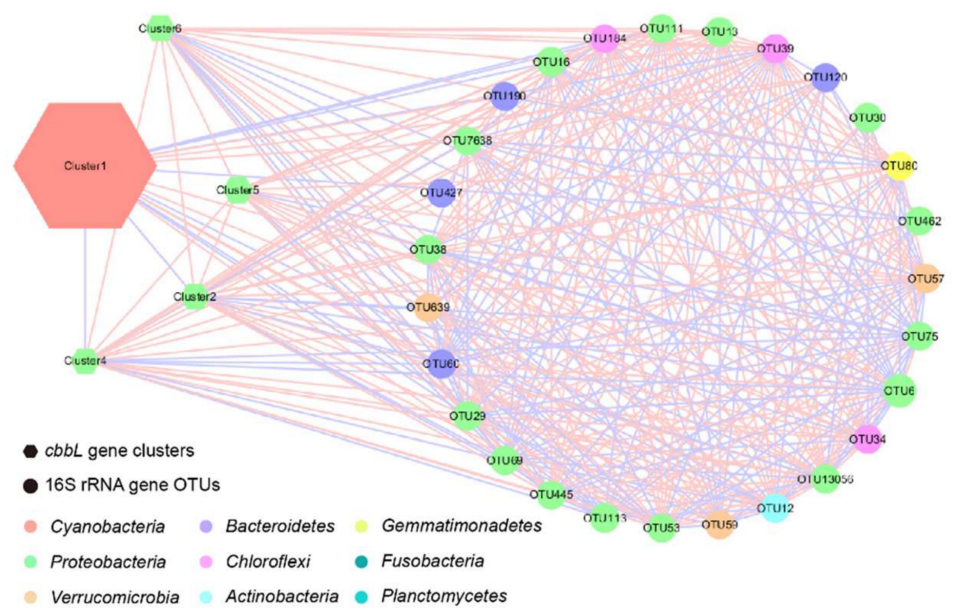

Figure 5. Correlation of key $16 \mathrm{~S}$ rRNA gene OTUs and $c b b L$ gene clusters. (A,B) Abundance of top 30 key $16 \mathrm{~S}$ rRNA gene OTUs in surface (A) and bottom water (B) selected by Random Forest machine learning. (C,D) The co-occurrence network of key $16 \mathrm{~S}$ rRNA gene OTUs and $c b b L$ gene clusters in surface water (C) and bottom water (D). Node size indicated the abundance of the OTU.

Partial mantel test was conducted to evaluate the correlation of environmental parameters with variation in $\beta$ NTI distribution. Coral coverage was the most important factor that correlated with both bacterial and carbon-fixation community in the surface and bottom. Nitrite concentration and $\mathrm{pH}$ were also correlated with both communities in surface water. Concentration of silicate and phosphate were correlated with bacterial and carbon-fixation community, respectively (Tables S5 and S6). 
(A)

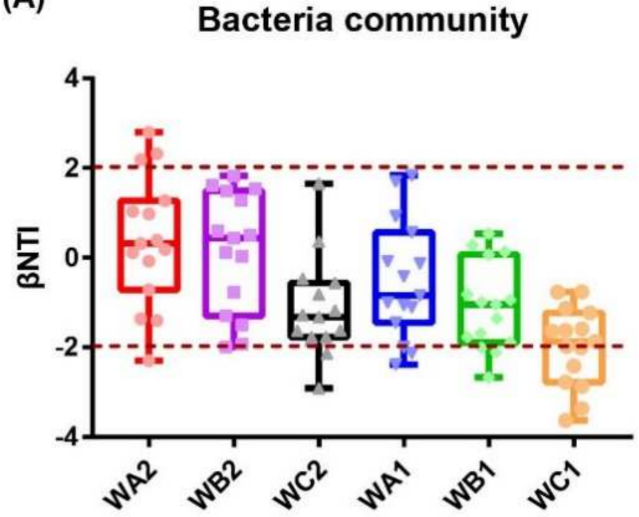

(B)

\section{Carbon-fixation community}

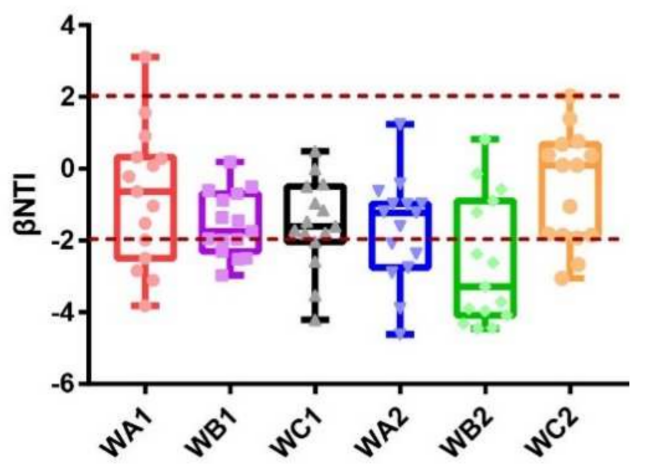

Figure 6. Distribution patterns of $\beta$ NTI values. (A) Bacterial communities in surface and bottom water. (B) Carbon-fixation bacterial communities in surface and bottom water. Horizontal dashed lines indicate lower and upper significance thresholds at -2 and +2 , respectively.

\section{Discussion}

Previous studies identified the water-associated microbial community structure in large scale surveys. In this study, we surveyed a high-latitude scleractinian coral community, providing more precise clues for interaction and assembly of bacterial and carbon-fixation bacterial community in water column.

\subsection{Environmental Drivers of the Bacterial Distribution in Coral-Associated Water Column}

Microbial community composition is closely related to the physical and chemical features of this habitat, including temperature, salinity, nutrients, and the hydrological regime [10]. Generally, bacterial community of inshore and other eutrophic reef waters with high nutrient concentrations comprised $37-73 \%$ of total biomass in heterotrophic microbes [38,39], dominated by Bacteroidetes and Proteobacteria, especially Gammaproteobacteria [40-42]. In this study, Proteobacteria, Actinobacteria, Cyanobacteria, and Bacteroidetes were dominant phylum in all samples, which was consistent with most previous studies. Synechococcus was the predominant autotrophic bacteria in eutrophic reef waters, and they usually comprised more than $90 \%$ of Cyanobacteria in tropical coastal ocean waters [39,43-45]. The nutrient level of seawater at Miaowan Island changed seasonally due to Pearl River runoff and human behavior [46]. Our study found that the concentrations of nitrate, ammonia, and phosphate were $0.29 \mathrm{mg} / \mathrm{L}, 0.022 \mathrm{mg} / \mathrm{L}$, and $0.003 \mathrm{mg} / \mathrm{L}$ (Table S7), respectively, indicating a eutrophic environment. So, Synechococcus were unsurprisingly the predominant autotrophs here.

The diversity of bacterial and carbon-fixation communities showed trends to increase when area shifting from coral-associated (WA and WB) to non-coral (WC). Moreover, community structures of bacteria and carbon-fixation bacteria were significantly different between coral-associated (WA and WB) and non-coral (WC) areas in surface and bottom water, indicating the distribution-specificity of communities. Similar shifting in bacterial community was also found in a cold-water coral reef ecosystem where the community structure changed significantly from reef center to the periphery in a small-scale, suggesting a significant biogeographic imprinting of seawater-associated community [16]. However, the dynamic of carbon-fixation community had not yet been identified before. Taken together, our results shed light on the dynamic of bacterial and carbon-fixer communities in water of a high-latitude scleractinian coral habitat, which indicates its sensitivity and correlation to the benthic community.

Furthermore, our results demonstrated that coral coverage ratio, nitrite, and nitrate significantly influence the bacterial and carbon-fixation bacterial community. Nitrogen supplement was one of the limitations for bacterial growth and productivity $[47,48]$. The symbionts of scleractinian coral were found to be able to fix nitrogen and nitride-enriched 
mucus was released into the seawater by corals, which is an essential nutrient for environmental microbes [49-52]. Additionally, the sediment is considered to be another nitrogen source in some coral reefs. The flux rates of inorganic nitrogen from the sediment to the water column were about $0.046 \mathrm{nmol} \mathrm{cm}^{-2} \mathrm{~h}^{-1}$ [53]. Taken together, nitrogen supplement associated with coral community may be the key environmental factor that impacts the water bacterial and carbon-fixation bacterial community. These results highlight that investigating the microbiome and their interactions in three environments, including the sediment, coral, and water, in an integrated manner, is critical for understanding the health and resilience of coral reefs as a single functioning ecosystem.

\subsection{Interactions between Heterotrophic Bacteria and Carbon-Fixation Bacteria}

Despite the environmental factors, the correlation of biotic factors within the microbial community is taken into consideration. Interactions between heterotrophic and photoautotrophic microbes are essential in the marine food web [54,55]. Heterotrophs utilize the organic carbon fixed by autotrophs. In return, they benefit photoautotrophs by providing essential micronutrients, such as vitamins, bioavailable trace metals, and amino acids [55-57], as well as reducing the levels of toxic reactive oxygen [58,59]. The co-culture system proved that the interaction between strictly heterotrophic bacteria and autotrophic strains played a crucial role in improving the $\mathrm{CO}_{2}$ fixing efficiency by eliminating self-restraint of organic compounds and promoting the autotrophic pathway [13]. Moreover, such interaction was usually changed by temperature, seawater $\mathrm{pH}$, and nutrient supplement [60-63]. Thus, the interactions between heterotrophic bacteria and carbon-fixers are essential for microbial community assembly. However, most of the researches were performed in the lab. Few clues were obtained from in situ environmental researches.

In this study, we analyzed the interaction of carbon-fixers and key bacteria. The key bacteria in the communities were largely identified as heterotrophs, making it possible to access their interactions in situ. The complexity of network in bottom water was more than on the surface. Moreover, the carbon-fixation taxa clusters were more connective to the heterotrophic bacteria in the bottom, suggesting a more interactive community there. Interestingly, the correlation pattern between carbon-fixation taxa correlated and heterotrophs showed evident difference in surface and bottom water. The clusters in the surface correlated with different heterotrophic taxa. However, in bottom water, clusters interacted with fewer lineages of heterotrophic taxa, except for the Cluster 1. SAR86, SAR11, and SAR202 were ubiquitous heterotrophs interacting with autotrophic clusters affiliated to Proteobacteria in the bottom water. These heterotrophic taxa are dominant bacteria in the ocean and usually co-occur with the autotrophs [64-67]. They mediate fundamental ecological processes, for example driving the geochemical cycles [64-66]. Our results indicate that Synechococcus (except for Cluster 1) may be in support with these key heterotrophs in our studying field.

On the other hand, the most abundant Cluster 1 affiliated to Synechococcus interacted with Bacteroidetes, Proteobacteria, and Verrucomicrobia taxa, suggesting they may be functionally correlated with carbon cycle in bottom water of high-latitude coral habitat. Additionally, Cluster 1 was found to interact with three taxa from Flavobacteriales, which were reported to be in need for rapid growth of Synechococcus [68]. Heterotrophic bacteria were able to help with the formation of picocyanobacteria aggregate, which was essential for the adaptation of these small cells living in subsurface water [69]. Taken together, most carbon-fixers (abundance $>84.7 \%$ ) closely interacted with heterotrophic bacteria in the bottom, suggesting more connective but less diverse interaction, as well as a more complex food and energy network at the bottom of scleractinian coral habitat. The debate on the role of coral reefs as a carbon source or sink never came to an end $[19,70]$. Our results provided some preliminary clues, at least in this high-latitude habitat, that carbon-fixers were more abundant in the center of coral habitat. In addition, they were more connective with heterotrophs as closer to the coral colonies in the bottom, indicating that corals may promote the carbon-fixation activity by seawater microbiome. 
4.3. Assembly of Environmental Bacterial and Carbon-Fixation Bacterial Community in Seawater of High-Latitude Coral Habitat

Microbial communities are governed by deterministic and stochastic processes, and both of them regulated the assembly of microbial community concurrently [71]. The assembly patterns of microbial community in large-scale coral reefs were well defined. In the Great Barrier Reef, the composition of the microbial community showed significantly higher similarity 'within' than 'between' samples collected from the same habitat but different time, suggesting that deterministic rather than stochastic processes drive their community assembly [15]. In another case, the assembly of microbial community in cold-water coral reef ecosystems was driven by both stochastic and deterministic processes [16]. Moreover, variable selection was identified to be the main factor determining the compositional change in the bacterial community in coral reefs of Red Sea [72]. However, the assembly pattern remained unclarified in high-latitude coral habitats.

In our study, we identified the assembly pattern of bacterial and carbon-fixation bacterial communities in seawater of a high-latitude scleractinian coral habitat. For bacterial community, deterministic and stochastic processes together drove the community assembly in surface water in the coral-associated (WA2) and non-coral (WC2) areas, but only stochastic processes existed in the transitional area (WB2). Interestingly, in the bottom water, the proportion of deterministic process gradually increased from the coral-associated area (WA1) to non-coral area (WC1), suggesting an increased impact of environmental factors on bacterial community assembly with a distance away from the center of coral habitat. This may due to the high primary production ratio of the coral community and increased nutrient supplement by corals [7], which induced lower competition among bacteria [73]. The concentration of nitrite and $\mathrm{pH}$ showed significant correlation between OTU abundance and $\beta$ NTI in surface water, suggesting they may be the key factors driving the assembly of bacterial community.

The assembly pattern of carbon-fixation bacterial community was poorly defined. Here in this study, we found that deterministic and stochastic processes co-existed, and the proportions were discrepant between stations, suggesting that assembly of carbonfixation bacterial community was affected by environmental factors with varying degrees. Community assembly was dominated by the deterministic process in surface water, while stochastic process dominated at the bottom. Nitrite and $\mathrm{pH}$ were strongly correlated with $\beta N T I$ in surface water, implicating that the assembly of carbon-fixation community was mainly driven by these parameters. However, phosphate was the only chemical parameter with weak correlation with $\beta$ NTI in bottom water, suggesting that there may be other undetermined environmental factors. Therefore, our results revealed the impacts of environmental conditions on assembly of bacterial and carbon-fixation bacterial communities in high-latitude coral habitat seawater, which may advance the understanding of formation and sustainment of coral reef at high-latitude area due to global warming.

\section{Conclusions}

In this study, we investigated the diversity of bacterial and carbon-fixation community in seawater of a high-latitude coral habitat in the northern SCS and revealed that the compositions of both communities significantly changed between different areas in the habitat. Heterotrophic bacteria were more connective with carbon-fixers in bottom water than in surface water, and the autotrophs tended to interact with fewer lineages of heterotrophic taxa in bottom water. The bacterial community assembly showed an increase by deterministic process with a decrease of coral coverage in bottom water, which may correlate with the gradient of nitrite concentration and $\mathrm{pH}$ in the habitat. The assembly of carbon-fixation communities did not show variation between different areas but water layers. The deterministic process was dominant in surface water, while the stochastic process was dominant at the bottom. 
Supplementary Materials: The following supporting information can be downloaded at: https:// www.mdpi.com/article/10.3390/microorganisms10030558/s1, Figure S1: Alpha diversity indices of bacterial community; Figure S2: Alpha diversity indices of carbon-fixation microbial community; Figure S3: Composition of bacterial and carbon-fixation microbial community; Table S1: Correlation of environmental variables with bacterial OTU abundance determined by partial Mantel tests; Table S2: Correlation of environmental variables with $c b b L$ gene OTU abundance determined by partial Mantel tests; Table S3: Correlation of key $16 \mathrm{~S}$ rRNA gene OTUs with $c b b L$ gene clusters in surface water; Table S4: Correlation of key $16 \mathrm{~S}$ rRNA gene OTUs with $c b b L$ gene clusters in bottom water; Table S5: Correlation of environmental variables with $\beta$ NTI values of bacterial community determined by partial Mantel tests; Table S6: Correlation of environmental variables with $\beta$ NTI values of carbonfixation microbial community determined by partial Mantel tests; Table S7: Environmental characters of all sampling sites.

Author Contributions: Conceptualization, Y.C., J.L. and S.Z.; methodology, Y.C. and Y.L.; software, Y.C., Q.L. and Y.Z.; investigation, Q.Y., X.T., X.Y. and Z.J.; writing-original draft preparation, Y.C.; writing-review and editing, Y.C., J.L. and S.Z.; visualization, Y.C.; supervision, J.L. and S.Z.; project administration, J.L.; funding acquisition, J.L. and S.Z. All authors have read and agreed to the published version of the manuscript.

Funding: This research was funded by National Natural Science Foundation of China (42122045 and 41890853), Key Special Project for Introduced Talents Team of Southern Marine Science and Engineering Guangdong Laboratory (Guangzhou) (GML2019ZD0401), K.C. Wong Education Foundation (GJTD-2020-12).

Institutional Review Board Statement: Not applicable.

Informed Consent Statement: Not applicable.

Data Availability Statement: The nucleotide sequences were deposited at the NCBI Sequence Read Archive under the BioProject number PRJNA762627.

Acknowledgments: We thank Junde Dong and Hui Huang for assistance with sampling and Huajun Zhang for discussion of community assembly. We are grateful to Yunchao Wu for analysis of DIC, DOC, and TOC parameters.

Conflicts of Interest: The authors declare no conflict of interest. The funders had no role in the design of the study; in the collection, analyses, or interpretation of data; in the writing of the manuscript, or in the decision to publish the results.

\section{References}

1. Connell, J.H. Diversity in tropical rain forests and coral reefs. Science 1978, 199, 1302-1310. [CrossRef]

2. Roberts, C.M.; McClean, C.J.; Veron, J.E.; Hawkins, J.P.; Allen, G.R.; McAllister, D.E.; Mittermeier, C.G.; Schueler, F.W.; Spalding, M.; Wells, F.; et al. Marine biodiversity hotspots and conservation priorities for tropical reefs. Science 2002, 295, 1280-1284. [CrossRef]

3. Van Hoytema, N.; Bednarz, V.N.; Cardini, U.; Naumann, M.S.; Al-Horani, F.A.; Wild, C. The influence of seasonality on benthic primary production in a red sea coral reef. Mar. Biol. 2016, 163, 52. [CrossRef]

4. Alldredge, A.L.; Carlson, C.A.; Carpenter, R.C. Sources of organic carbon to coral reef flats. Oceanography 2013, 26, 108-113. [CrossRef]

5. Cardini, U.; Bednarz, V.N.; van Hoytema, N.; Rovere, A.; Naumann, M.S.; Al-Rshaidat, M.; Wild, C. Budget of primary production and dinitrogen fixation in a highly seasonal red sea coral reef. Ecosystems 2016, 19, 771-785. [CrossRef]

6. Hatcher, B.G. Coral reef primary productivity: A beggar's banquet. Trends Ecol. Evol. 1988, 3, 106-111. [CrossRef]

7. Silveira, C.B.; Cavalcanti, G.S.; Walter, J.M.; Silva-Lima, A.W.; Dinsdale, E.A.; Bourne, D.G.; Thompson, C.C.; Thompson, F.L. Microbial processes driving coral reef organic carbon flow. FEMS Microbiol. Rev. 2017, 41, 575-595. [CrossRef]

8. Garren, M.; Azam, F. New directions in coral reef microbial ecology. Environ. Microbiol. 2012, 14, 833-844. [CrossRef]

9. Kegler, H.F.; Lukman, M.; Teichberg, M.; Plass-Johnson, J.; Hassenrück, C.; Wild, C.; Gärdes, A. Bacterial community composition and potential driving factors in different reef habitats of the spermonde archipelago, indonesia. Front. Microbiol. $2017,8,662$. [CrossRef]

10. Voolstra, C.R.; Berumen, M.L. Coral Reefs of the Red Sea; Springer: Berlin/Heidelberg, Germany, 2019.

11. Furby, K.A.; Apprill, A.; Cervino, J.M.; Ossolinski, J.E.; Hughen, K.A. Incidence of lesions on fungiidae corals in the eastern red sea is related to water temperature and coastal pollution. Mar. Environ. Res. 2014, 98, 29-38. [CrossRef] 
12. Locarnini, M.; Mishonov, A.; Baranova, O.; Boyer, T.; Zweng, M.; Garcia, H.; Seidov, D.; Weathers, K.; Paver, C.; Smolyar, I. World Ocean Atlas 2018. Volume 1: Temperature; U.S. Department of Commerce: Washington, DC, USA, 2018.

13. Hu, J.; Wang, L.; Zhang, S.; Xi, X.; Le, Y.; Fu, X.; Tsang, Y.; Gao, M. Interactions between autotrophic and heterotrophic strains improve $\mathrm{CO}_{2}$ fixing efficiency of non-photosynthetic microbial communities. Appl. Biochem. Biotechnol. 2015, 176, $1459-1471$. [CrossRef]

14. Wang, J.; Shen, J.I.; Wu, Y.; Tu, C.; Soininen, J.; Stegen, J.C.; He, J.; Liu, X.; Zhang, L.; Zhang, E. Phylogenetic beta diversity in bacterial assemblages across ecosystems: Deterministic versus stochastic processes. ISME J. 2013, 7, 1310-1321. [CrossRef]

15. Glasl, B.; Bourne, D.G.; Frade, P.R.; Thomas, T.; Schaffelke, B.; Webster, N.S. Microbial indicators of environmental perturbations in coral reef ecosystems. Microbiome 2019, 7, 94. [CrossRef]

16. Schoettner, S.; Wild, C.; Hoffmann, F.; Boetius, A.; Ramette, A. Spatial scales of bacterial diversity in cold-water coral reef ecosystems. PLoS ONE 2012, 7, e32093. [CrossRef]

17. Kinsey, D.; Hopley, D. The significance of coral reefs as global carbon sinks-Response to greenhouse. Palaeogeogr. Palaeoclimatol. Palaeoecol. 1991, 89, 363-377. [CrossRef]

18. Kayanne, H.; Suzuki, A.; Saito, H. Diurnal changes in the partial pressure of carbon dioxide in coral reef water. Science 1995, 269, 214-216. [CrossRef]

19. Chisholm, J.R.; Barnes, D.J. Anomalies in coral reef community metabolism and their potential importance in the reef $\mathrm{CO}_{2}$ source-sink debate. Proc. Natl. Acad. Sci. USA 1998, 95, 6566-6569. [CrossRef]

20. Precht, W.F.; Aronson, R.B. Climate flickers and range shifts of reef corals. Front. Ecol. Environ. 2004, 2, 307-314. [CrossRef]

21. Greenstein, B.J.; Pandolfi, J.M. Escaping the heat: Range shifts of reef coral taxa in coastal western Australia. Glob. Change Biol. 2008, 14, 513-528. [CrossRef]

22. Yamano, H.; Sugihara, K.; Nomura, K. Rapid poleward range expansion of tropical reef corals in response to rising sea surface temperatures. Geophys. Res. Lett. 2011, 38, L04601. [CrossRef]

23. Beger, M.; Sommer, B.; Harrison, P.L.; Smith, S.D.; Pandolfi, J.M. Conserving potential coral reef refuges at high latitudes. Div. Distrib. 2014, 20, 245-257. [CrossRef]

24. Li, J.; Long, L.; Zou, Y.; Zhang, S. Microbial community and transcriptional responses to increased temperatures in coral pocillopora damicornis holobiont. Environ. Microbiol. 2021, 23, 826-843. [CrossRef] [PubMed]

25. Zhao, Y.; Liu, P.; Rui, J.; Cheng, L.; Wang, Q.; Liu, X.; Yuan, Q. Dark carbon fixation and chemolithotrophic microbial community in surface sediments of the cascade reservoirs, southwest china. Sci. Total Environ. 2020, 698, 134316. [CrossRef]

26. Chen, S.; Zhou, Y.; Chen, Y.; Gu, J. Fastp: An ultra-fast all-in-one fastq preprocessor. Bioinformatics 2018, 34, i884-i890. [CrossRef]

27. Edgar, R.C. Search and clustering orders of magnitude faster than blast. Bioinformatics 2010, 26, 2460-2461. [CrossRef]

28. Caporaso, J.G.; Kuczynski, J.; Stombaugh, J.; Bittinger, K.; Bushman, F.D.; Costello, E.K.; Fierer, N.; Peña, A.G.; Goodrich, J.K.; Gordon, J.I.; et al. Qiime allows analysis of high-throughput community sequencing data. Nat. Methods 2010, 7, 335-336. [CrossRef] [PubMed]

29. Edgar, R.C. Uparse: Highly accurate otu sequences from microbial amplicon reads. Nat. Methods 2013, 10, 996-998. [CrossRef]

30. Edgar, R.C.; Haas, B.J.; Clemente, J.C.; Quince, C.; Knight, R. Uchime improves sensitivity and speed of chimera detection. Bioinformatics 2011, 27, 2194-2200. [CrossRef]

31. Rognes, T.; Flouri, T.; Nichols, B.; Quince, C.; Mahe, F. Vsearch: A versatile open source tool for metagenomics. Peerj 2016, 4, e2584. [CrossRef] [PubMed]

32. Bokulich, N.A.; Subramanian, S.; Faith, J.J.; Gevers, D.; Gordon, J.I.; Knight, R.; Mills, D.A.; Caporaso, J.G. Quality-filtering vastly improves diversity estimates from illumina amplicon sequencing. Nat. Methods 2013, 10, 57-59. [CrossRef]

33. Kembel, S.W.; Cowan, P.D.; Helmus, M.R.; Cornwell, W.K.; Morlon, H.; Ackerly, D.D.; Blomberg, S.P.; Webb, C.O. Picante: R tools for integrating phylogenies and ecology. Bioinformatics 2010, 26, 1463-1464. [CrossRef] [PubMed]

34. Oksanen, J.; Blanchet, F.G.; Kindt, R.; Legendre, P.; Minchin, P.R.; O'hara, R.; Simpson, G.L.; Solymos, P.; Stevens, M.H.H.; Wagner, H. Package 'vegan'. Commun. Ecol. Package 2013, 2, 1-295.

35. Kumar, S.; Stecher, G.; Li, M.; Knyaz, C.; Tamura, K. Mega x: Molecular evolutionary genetics analysis across computing platforms. Mol. Biol. Evol. 2018, 35, 1547-1549. [CrossRef] [PubMed]

36. Liaw, A.; Wiener, M. Classification and regression by randomforest. $R$ News 2002, 2, 18-22.

37. Stegen, J.C.; Lin, X.; Fredrickson, J.K.; Chen, X.; Kennedy, D.W.; Murray, C.J.; Rockhold, M.L.; Konopka, A. Quantifying community assembly processes and identifying features that impose them. ISME J. 2013, 7, 2069-2079. [CrossRef]

38. Bruce, T.; Meirelles, P.M.; Garcia, G.; Paranhos, R.; Rezende, C.E.; de Moura, R.L.; Coni, E.O.; Vasconcelos, A.T.; Amado Filho, G.; Hatay, M. Abrolhos bank reef health evaluated by means of water quality, microbial diversity, benthic cover, and fish biomass data. PLoS ONE 2012, 7, e36687. [CrossRef]

39. Frade, P.R.; Glasl, B.; Matthews, S.A.; Mellin, C.; Serrão, E.A.; Wolfe, K.; Mumby, P.J.; Webster, N.S.; Bourne, D.G. Spatial patterns of microbial communities across surface waters of the great barrier reef. Commun. Biol. 2020, 3, 442. [CrossRef]

40. Luo, H.; Moran, M.A. How do divergent ecological strategies emerge among marine bacterioplankton lineages? Trends Microbiol. 2015, 23, 577-584. [CrossRef]

41. Laas, P.; Ugarelli, K.; Absten, M.; Boyer, B.; Briceño, H.; Stingl, U. Composition of prokaryotic and eukaryotic microbial communities in waters around the florida reef tract. Microorganisms 2021, 9, 1120. [CrossRef] 
42. Neave, M.J.; Apprill, A.; Aeby, G.; Miyake, S.; Voolstra, C.R. Microbial communities of red sea coral reefs. Coral Reefs Red Sea 2019, $4,53-68$.

43. Kelly, L.W.; Williams, G.J.; Barott, K.L.; Carlson, C.A.; Dinsdale, E.A.; Edwards, R.A.; Haas, A.F.; Haynes, M.; Lim, Y.W.; McDole, T. Local genomic adaptation of coral reef-associated microbiomes to gradients of natural variability and anthropogenic stressors. Proc. Natl. Acad. Sci. USA 2014, 111, 10227-10232. [CrossRef] [PubMed]

44. Nelson, C.E.; Alldredge, A.L.; McCliment, E.A.; Amaral-Zettler, L.A.; Carlson, C.A. Depleted dissolved organic carbon and distinct bacterial communities in the water column of a rapid-flushing coral reef ecosystem. ISME J. 2011, 5, 1374-1387. [CrossRef] [PubMed]

45. Weber, L.; González-Díaz, P.; Armenteros, M.; Ferrer, V.M.; Bretos, F.; Bartels, E.; Santoro, A.E.; Apprill, A. Microbial signatures of protected and impacted northern caribbean reefs: Changes from cuba to the florida keys. Environ. Microbiol. 2020, 22, 499-519. [CrossRef] [PubMed]

46. Lu, Y.; Ding, Z.; Li, W.; Chen, X.; Yu, Y.; Zhao, X.; Lian, X.; Wang, Y. The effect of seawater environmental factors on the corals of wailingding island in the pearl river estuary. Cont. Shelf Res. 2020, 197, 104087. [CrossRef]

47. Moore, C.M.; Mills, M.M.; Langlois, R.; Milne, A.; Achterberg, E.P.; La Roche, J.; Geider, R.J. Relative influence of nitrogen and phosphorous availability on phytoplankton physiology and productivity in the oligotrophic sub-tropical north Atlantic Ocean Limnol. Oceanogr. 2008, 53, 291-305. [CrossRef]

48. Moore, C.; Mills, M.; Arrigo, K.; Berman-Frank, I.; Bopp, L.; Boyd, P.; Galbraith, E.; Geider, R.; Guieu, C.; Jaccard, S. Processes and patterns of oceanic nutrient limitation. Nat. Geosci. 2013, 6, 701-710. [CrossRef]

49. Coles, S.L.; Strathmann, R. Observations on coral mucus "flocs" and their potential trophic significance 1. Limnol. Oceanogr. 1973, 18, 673-678. [CrossRef]

50. Kurihara, H.; Ikeda, N.; Umezawa, Y. Diurnal and seasonal variation of particle and dissolved organic matter release by the coral acropora tenuis. Peerj 2018, 6, e5728. [CrossRef]

51. Moynihan, M.A.; Goodkin, N.F.; Morgan, K.M.; Kho, P.Y.; Lopes dos Santos, A.; Lauro, F.M.; Baker, D.M.; Martin, P. Coralassociated nitrogen fixation rates and diazotrophic diversity on a nutrient-replete equatorial reef. ISME J. 2022, 16, 233-246. [CrossRef]

52. Lesser, M.P.; Morrow, K.M.; Pankey, S.M.; Noonan, S.H. Diazotroph diversity and nitrogen fixation in the coral stylophora pistillata from the great barrier reef. ISME J. 2018, 12, 813-824. [CrossRef]

53. El-Khaled, Y.C.; Roth, F.; Rädecker, N.; Tilstra, A.; Karcher, D.B.; Kürten, B.; Jones, B.H.; Voolstra, C.R.; Wild, C. Nitrogen fixation and denitrification activity differ between coral- and algae-dominated red sea reefs. Sci. Rep. 2021, 11, 11820. [CrossRef]

54. Buchan, A.; LeCleir, G.R.; Gulvik, C.A.; González, J.M. Master recyclers: Features and functions of bacteria associated with phytoplankton blooms. Nat. Rev. Microbiol. 2014, 12, 686-698. [CrossRef]

55. Zheng, Q.; Wang, Y.; Lu, J.; Lin, W.; Chen, F.; Jiao, N. Metagenomic and metaproteomic insights into photoautotrophic and heterotrophic interactions in a synechococcus culture. MBio 2020, 11, e03261-19. [CrossRef] [PubMed]

56. Amin, S.A.; Green, D.H.; Hart, M.C.; Küpper, F.C.; Sunda, W.G.; Carrano, C.J. Photolysis of iron-siderophore chelates promotes bacterial-algal mutualism. Proc. Natl. Acad. Sci. USA 2009, 106, 17071-17076. [CrossRef] [PubMed]

57. Kazamia, E.; Czesnick, H.; Nguyen, T.T.V.; Croft, M.T.; Sherwood, E.; Sasso, S.; Hodson, S.J.; Warren, M.J.; Smith, A.G. Mutualistic interactions between vitamin b12-dependent algae and heterotrophic bacteria exhibit regulation. Environ. Microbiol. 2012, 14, 1466-1476. [CrossRef] [PubMed]

58. Morris, J.J.; Kirkegaard, R.; Szul, M.J.; Johnson, Z.I.; Zinser, E.R. Facilitation of robust growth of prochlorococcus colonies and dilute liquid cultures by "helper" heterotrophic bacteria. Appl. Environ. Microbiol. 2008, 74, 4530-4534. [CrossRef]

59. Morris, J.J.; Johnson, Z.I.; Szul, M.J.; Keller, M.; Zinser, E.R. Dependence of the cyanobacterium prochlorococcus on hydrogen peroxide scavenging microbes for growth at the ocean's surface. PLoS ONE 2011, 6, e16805. [CrossRef] [PubMed]

60. Labban, A.; Palacio, A.S.; García, F.C.; Hadaidi, G.; Ansari, M.I.; López-Urrutia, Á.; Alonso-Sáez, L.; Hong, P.-Y.; Morán, X.A.G Temperature responses of heterotrophic bacteria in co-culture with a red sea synechococcus strain. Front. Microbiol. 2021, 12, 612732. [CrossRef]

61. Arandia-Gorostidi, N.; Weber, P.K.; Alonso-Sáez, L.; Morán, X.A.G.; Mayali, X. Elevated temperature increases carbon and nitrogen fluxes between phytoplankton and heterotrophic bacteria through physical attachment. ISME J. 2017, 11, 641-650. [CrossRef]

62. Hornick, T.; Bach, L.T.; Crawfurd, K.J.; Spilling, K.; Achterberg, E.; Brussaard, C.; Riebesell, U.; Grossart, H. Ocean acidification indirectly alters trophic interaction of heterotrophic bacteria at low nutrient conditions. Biogeosci. Discuss. 2016, 10, 61.

63. Zhang, R.; Jiang, T.; Tian, Y.; Xie, S.; Zhou, L.; Li, Q.; Jiao, N. Volcanic ash stimulates growth of marine autotrophic and heterotrophic microorganisms. Geology 2017, 45, 679-682. [CrossRef]

64. Hoarfrost, A.; Nayfach, S.; Ladau, J.; Yooseph, S.; Arnosti, C.; Dupont, C.L.; Pollard, K.S. Global ecotypes in the ubiquitous marine clade sar86. ISME J. 2020, 14, 178-188. [CrossRef] [PubMed]

65. Mehrshad, M.; Rodriguez-Valera, F.; Amoozegar, M.A.; López-García, P.; Ghai, R. The enigmatic sar202 cluster up close: Shedding light on a globally distributed dark ocean lineage involved in sulfur cycling. ISME J. 2018, 12, 655-668. [CrossRef] [PubMed]

66. Giovannoni, S.J. Sar11 bacteria: The most abundant plankton in the oceans. Ann. Rev. Mar. Sci. 2017, 9, 231-255. [CrossRef] [PubMed] 
67. Pajares, S.; Varona-Cordero, F.; Hernández-Becerril, D.U. Spatial distribution patterns of bacterioplankton in the oxygen minimum zone of the tropical mexican pacific. Microb. Ecol. 2020, 80, 519-536. [CrossRef]

68. Zheng, Q.; Wang, Y.; Xie, R.; Lang, A.S.; Liu, Y.; Lu, J.; Zhang, X.; Sun, J.; Suttle, C.A.; Jiao, N. Dynamics of heterotrophic bacterial assemblages within synechococcus cultures. Appl. Environ. Microbiol. 2018, 84, e01517. [CrossRef]

69. Cruz, B.N.; Neuer, S. Heterotrophic bacteria enhance the aggregation of the marine picocyanobacteria prochlorococcus and synechococcus. Front. Microbiol. 2019, 10, 1864. [CrossRef]

70. Watanabe, A.; Nakamura, T. Carbon dynamics in coral reefs. In Blue Carbon in Shallow Coastal Ecosystems; Springer: Singapore, 2019; pp. 273-293.

71. Stegen, J.C.; Lin, X.; Konopka, A.E.; Fredrickson, J.K. Stochastic and deterministic assembly processes in subsurface microbial communities. ISME J. 2012, 6, 1653-1664. [CrossRef]

72. Pearman, J.K.; Aylagas, E.; Voolstra, C.R.; Anlauf, H.; Villalobos, R.; Carvalho, S. Disentangling the complex microbial community of coral reefs using standardized autonomous reef monitoring structures (arms). Mol. Ecol. 2019, 28, 3496-3507. [CrossRef]

73. Hibbing, M.E.; Fuqua, C.; Parsek, M.R.; Peterson, S.B. Bacterial competition: Surviving and thriving in the microbial jungle. Nat. Rev. Microbiol. 2010, 8, 15-25. [CrossRef] 